\title{
JUSTIFICATION OF THE CHOICE OF PUBLIC TRANSPORT SERVICE TYPE ON THE ROUTE
}

\author{
Skirkouski S. V. ${ }^{1}$, Sedziukevich U. M. ${ }^{2}$, Svichynska O. V. ${ }^{3}$ \\ ${ }^{1}$ Belorussian State University of Transport, \\ ${ }^{2}$ Belarusian National Technical University, \\ ${ }^{3}$ Kharkiv National Automobile and Highway University
}

\begin{abstract}
Problem. Currently, there exist two main types of service on public transport routes headway-based and timetable-based. They differ by the frequency of service at the stops and by the information available for passengers. The required frequency of service significantly affects transport operator costs and passenger travel time which, in turn, influences the cost for a passenger. One of the ways to reduce costs for both parties of the transportation process is to make a reasonable choice of the type of service or switch between the types during the day depending on the passenger flow volume. Goal. In the paper, to justify the choice of between the types of service, the cost of public transport vehicles operation and the losses of passenger travel times are taken into account. Methodology. The developed way of making a choice about the type of service allows increasing the efficiency of urban public transport due to reducing the passenger waiting time by switching from the headway-based service in rush hours to timetable-based service in the periods of passenger flow volume decline. Results. The relationship allowing making a decision about the type of service on the route is developed. It allows to correctly introduce the type of service which will ensure the balance between the transport operator and passenger costs. Originality. The developed approach to make a decision on the type of service allows reducing the passenger waiting time by switching from headway-based service in rush hours to the timetable-based service in the periods of decline in passenger flow volume during the day. Practical value. The results of the research based on the survey data allowed estimating the numerical value of the headway at which it is expedient to switch to the timetable-based service.
\end{abstract}

Key words: passenger transportation, public transport, type of service, headway, waiting time.

\section{Introduction}

The main objective of the organization of urban public transport (UPT) operation is to provide passengers with high-quality service at a minimal cost. To improve the UPT efficiency, it is possible to change the type of public transport service on the route in order to reduce passenger travel time while maintaining the achieved level of service [1]. In this case, the task is to determine the number of public transport vehicles (or equally, the headway) required to handle existing passenger flows as well as to choose the type of service - timetable-based or headway-based. This task should be solved when transitioning from peak to off-peak periods and vice versa.

\section{Literature review}

Public transport operations can provide the urban population with services of different types. These types can be classified according to the way of stop servicing and the way of providing passengers with information about service frequency.
The first classification includes two main service types - conventional service and express service [2].

Conventional service means that public transport vehicle (PTV) will stop and pick up passengers at every stop on the route. Express service means that PTV will stop at a limited number of stops which is less than on a conventional route. This type of service needs to meet the prerequisites for putting into practice and allows increasing speed of the vehicles and, accordingly, reducing passenger travel times without changes in a fleet operating on the route [2].

The second classification also includes two types of services - headway-based and timetablebased [3-5]. Headway-based service means that passengers have only the information about the headway on the route. In this case, PTV usually operates at a relatively high frequency, and it allows passengers do not to plan their arrival at the origin stop - passengers just come to the stop and wait for some time for PTV. Many researchers usually consider waiting time as half of the headway [5]. 
Timetable-based service means that there exists a published timetable for a certain route, and this timetable is available for passengers. The timetable can be published online and placed at each stop of the route. At that, passengers can be supported with supplementary information about real-time information about public transport operation [6]. Under these conditions, public transport users can plan their arrival at the origin stop and therefore reduce their waiting time or even make it close to zero.

These types of services require attention because the right choice of a certain type can potentially achieve the balance between the cost of operator and passenger. For example, timetablebased service can allow an operator to reduce the number of vehicles on the route but in this case, passengers should be provided with the timetable to reduce their waiting time and, accordingly, travel time. On the other hand, headway-based service can attract passengers due to high service frequency but it requires higher operator costs [7,8].

So, the well-grounded decision on when it is reasonable to use a certain type of service can positively affect the operator performance and passenger level of satisfaction with public transport use.

The aim and problem statement

To determine the moment when it is reasonable to change the type of service, it is proposed to use such criterion as the total cost which includes the losses caused by the decrease in passenger transportation volume, the losses of the passengers related to waiting for boarding to the PTV, the costs of the carrier caused by the used type of service $\left(\mathrm{Z}_{\mathrm{T}}\right.$ for the timetable-based service and $\mathrm{Z}_{\mathrm{H}}$ for the headway-based service).

The equation allowing choosing a certain type of service on the route looks as follows:

$$
\begin{gathered}
Z_{\mathrm{T}} \leq Z_{\mathrm{H}}, \\
Z_{\mathrm{T}}=Q_{\mathrm{pf}} t_{\mathrm{wT}} C_{\mathrm{ph}}+\frac{A_{\mathrm{T}} l_{\mathrm{r}}}{t_{\mathrm{o}}} S_{\mathrm{km}}+ \\
+A_{\mathrm{T}} S_{\mathrm{h}}+\left(A_{\mathrm{e}}-A_{\mathrm{T}}\right) S_{\text {idle }}, \\
Z_{\mathrm{H}}=Q_{\mathrm{pf}} t_{\mathrm{wH}} C_{\mathrm{ph}}+\frac{A_{\mathrm{H}} l_{\mathrm{r}}}{t_{\mathrm{r}}} S_{\mathrm{km}}+ \\
+A_{\mathrm{H}} S_{h}+\left(A_{\mathrm{e}}-A_{\mathrm{T}}\right) S_{\text {idle }}
\end{gathered}
$$

where $Q_{\mathrm{pf}}$ is the passenger flow on the busiest section of the route, pas./h;
$t_{\mathrm{wT}}, t_{\mathrm{wH}}$ is average passenger waiting time when the type of service is timetable-based and headway-based accordingly, h;

$C_{\mathrm{ph}}$ is the cost of passenger-hour spent for waiting for boarding, bel. rub/h;

$A_{\mathrm{T}}, A_{\mathrm{H}}$ is the number of PTVs when the type of service is timetable-based and headwaybased accordingly;

$l_{\mathrm{r}}$ is the length of the round trip, $\mathrm{km}$;

$\mathrm{A}_{e}$ is the estimated number of PTVs required for the operation on a certain route (taking into account the reserve vehicles);

$t_{\mathrm{r}}$ is round trip time for a certain route, $\mathrm{h}$;

$S_{\mathrm{km}}$ is the variable costs per $1 \mathrm{~km}$ covered by PTV on the route, bel. rub/km;

$S_{h}$ is the fixed costs per 1 hour of PTV operation, bel. rub/h;

$S_{\text {idle }}$ is the fixed costs per 1 hour of PTV idle time, bel. rub/h.

The number of PTVs required for the operation on a certain route can be calculated as follows:

$$
A_{\mathrm{e}}=\frac{Q_{\mathrm{pf}} t_{\mathrm{r}}}{q_{\mathrm{opt}} \gamma}=\frac{t_{\mathrm{r}}}{I}
$$

where $q_{\text {опт }}$ is the optimal PTV capacity, pas;

$\gamma$ is the capacity ratio;

$I$ is the headway on the route, h $[1,9]$.

When the type of service is timetable-based, the number of PTVs can be calculated using the formula

$$
A_{\mathrm{T}}=A_{\mathrm{e}} K_{\mathrm{res}},
$$

where $K_{\text {res }}$ is the PTVs reservation ratio for the timetable-based service which is a percentage of the total number of PTVs operating on the route [10].

The optimal PTV capacity can be estimated as follows [11]:

$$
\begin{gathered}
q_{\mathrm{opt}}=\sqrt{\frac{2 Q_{\mathrm{pf}}}{C_{\mathrm{ph}}}} \times \\
\times \sqrt{\frac{k_{\mathrm{p}}\left[l_{\mathrm{r}} a_{\mathrm{km}}+a_{\mathrm{h}}\left(l_{\mathrm{r}} / v_{\mathrm{t}}+t_{\mathrm{wt}}\right)\right]}{\eta_{\mathrm{to}}}},
\end{gathered}
$$

where $k_{\mathrm{p}}$ is the ratio of passenger flow pulsation; 
$a_{\mathrm{km}}, a_{\mathrm{h}}$ are the coefficients of the relationship between vehicle capacity and the cost of passenger transportation;

$v_{\mathrm{t}}$ is the technical speed of the PTV, $\mathrm{km} / \mathrm{h}$;

$t_{\mathrm{wt}}$ is the idle time at the terminal stops, $\mathrm{h}$;

$\eta_{\text {to }}$ is the passenger turnover ratio [11].

For the headway-based service, the waiting time can be estimated as

$$
t_{\mathrm{wH}}=\frac{I}{2} .
$$

For the timetable-based service, the waiting time $t_{\mathrm{wT}}$ can be determined based on a statistical analysis of the empirical data.

Substituting equations (5) and (6) into expressions (2) and (3) will result in the following formulas:

$$
\begin{aligned}
Z_{\mathrm{T}}=Q_{\mathrm{pf}} & \left(t_{\mathrm{wT}} C_{\mathrm{ph}}+\frac{l_{\mathrm{r}}}{q_{\mathrm{T}} \gamma_{\mathrm{T}}} S_{\mathrm{km}}+\frac{t_{r}}{q_{\mathrm{T}} \gamma_{\mathrm{T}}} S_{h}\right)+ \\
& +\left(A_{\mathrm{e}} K_{\mathrm{res}}-\frac{Q_{\mathrm{pf}} t_{\mathrm{r}}}{q_{\mathrm{T}} \gamma_{\mathrm{T}}}\right) S_{\text {idle }}, \\
Z_{\mathrm{H}}=Q_{\mathrm{pf}} & \left(\frac{I}{2} C_{\mathrm{ph}}+\frac{l_{\mathrm{r}}}{q_{\mathrm{H}} \gamma_{\mathrm{H}}} S_{\mathrm{km}}+\frac{t_{\mathrm{r}}}{q_{\mathrm{H}} \gamma_{\mathrm{H}}} S_{\mathrm{h}}\right)+ \\
& +\left(A_{\mathrm{e}}-\frac{Q_{\mathrm{pf}} t_{\mathrm{r}}}{q_{\mathrm{H}} \gamma_{\mathrm{H}}}\right) S_{\text {idle }} .
\end{aligned}
$$

Equation (8) shows the sum of passenger costs related to their waiting for boarding and the carrier costs required to provide timetable-based service. Equation (9) represents the analogous sum of costs for the case of headway-based service. If $Z_{\mathrm{T}}$ is less than or equal to $Z_{\mathrm{H}}$ then it is reasonable to provide timetable-based service. Otherwise, the headway-based service will be more efficient. Thus, equations (8) and (9) allow deciding on the type of service on the route.

\section{Development of the approach for choosing the type of service on the route}

To develop the approach for choosing the type of service on the route, it is reasonable to graphically interpret formulas (8) and (9), Fig. 1.

The graphs in Fig. 1 testify that it is advisable to organize the timetable-based service when the frequency of the vehicles on the route is one vehicle in 10 to 20 minutes.

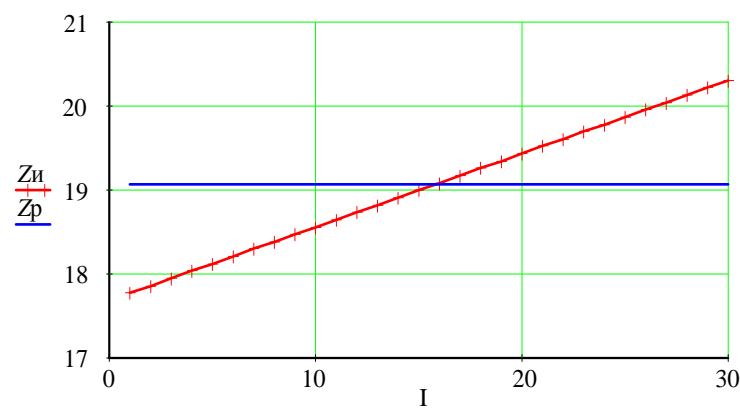

Fig. 1. The relationship between the total costs $Z_{\mathrm{T}}$ and $Z_{\mathrm{H}}$ and the headway on the route

To find the value of the headway at which it is reasonable to shift to the headway-based service, it is necessary to transform equations (8) and (9) with respect to $I$. Assuming that $q_{\mathrm{T}} \gamma_{\mathrm{T}}=q_{\mathrm{H}} \gamma_{\mathrm{H}}=q \gamma q_{\text {и }} \gamma_{\text {и }}$ and $A_{\mathrm{e}}=t_{\mathrm{r}} / I$, we can get the following:

$$
\begin{gathered}
Z_{\mathrm{p}}=Z_{\mathrm{r}}, \\
Q_{\mathrm{pf}}\left(t_{\mathrm{wT}} C_{\mathrm{ph}}+\frac{l_{\mathrm{r}}}{q \gamma} S_{\mathrm{km}}+\frac{t_{\mathrm{r}}}{q \gamma} S_{\mathrm{h}}\right)+ \\
+\left(\frac{t_{\mathrm{r}}}{I} K_{\mathrm{res}}-\frac{Q_{\mathrm{pf}} t_{\mathrm{r}}}{q \gamma}\right) S_{\text {idle }}= \\
=Q_{\mathrm{pf}}\left(\frac{I}{2} C_{\mathrm{ph}}+\frac{l_{\mathrm{r}}}{q \gamma} S_{\mathrm{km}}+\frac{t_{\mathrm{r}}}{q \gamma} S_{\mathrm{h}}\right)+ \\
+\left(A_{\mathrm{e}}-\frac{Q_{\mathrm{pf}} t_{\mathrm{r}}}{q \gamma}\right) S_{\text {idle }} .
\end{gathered}
$$

After transformations and under the assumption that $S_{\mathrm{r}}=S_{\text {idle }} / Q_{\mathrm{pf}}$, we can obtain

$$
t_{\mathrm{wT}} C_{\mathrm{ph}}+\frac{t_{\mathrm{r}}}{I} S_{\mathrm{r}}\left(K_{\mathrm{res}}-1\right)-\frac{I}{2} C_{\mathrm{ph}}=0,
$$

or

$$
t_{\mathrm{wT}} C_{\mathrm{ph}} I+t_{\mathrm{r}} S_{\mathrm{r}}\left(K_{\mathrm{res}}-1\right)-\frac{I^{2}}{2} \mathrm{C}_{\mathrm{ph}}=0 .
$$

where $S_{\mathrm{r}}$ is the specific reduced costs for the maintenance of reserve PTVs, bel. rub./pas.

Thus, the solution of the latter equation with respect to $I$ will be as follows: 
$I=\frac{\sqrt{\left(t_{\mathrm{wT}} C_{\mathrm{ph}}\right)^{2}+2 C_{\mathrm{ph}} t_{\mathrm{r}} S_{\mathrm{r}}\left(K_{\mathrm{res}}-1\right)}}{C_{\mathrm{ph}}}+\frac{t_{\mathrm{wT}} C_{\mathrm{ph}}}{C_{\mathrm{ph}}}(14)$

or

$$
I=\sqrt{t_{\mathrm{wT}}^{2}+\frac{2 t_{\mathrm{r}} S_{\mathrm{r}}\left(K_{\mathrm{res}}-1\right)}{C_{\mathrm{ph}}}}+t_{\mathrm{wT}} .
$$

After the substitutions based on the research data from the papers $[1,9-11]$ as well as the existing cost indicators, it is possible to obtain

$$
I=\sqrt{t_{\mathrm{wT}}^{2}+0,0186}+t_{\mathrm{wT}} .
$$

To determine the values of $t_{\mathrm{wT}}$ when the type of service is timetable-based, a survey in the city of Gomel was conducted. In order to get the characteristic of the total population on the base of the sample, the sample units should correctly represent the population. Thus, the sample should cover all the quotas in the population, i.e. it should be representative.

According to the law of large numbers, it can be argued that the sample is representative if each sample unit is selected randomly from the population, and all objects have an equal probability to be selected. If the sample size is large and the sample is a small share of the population, the difference between repeated and nonrepeated sample is nonsignificant. The total population is limited by the number of city inhabitants. The population of Gomel is approximately 526,9 thousand people, including 330 thousand working-age people. UPT in Gomel transports more than 250 thousand passengers per day [12]. Given the large total population, it is necessary to determine sufficient sample size. The size of the non-repeated sample can be determined using the formula

$$
n \geq \frac{t^{2} \delta^{2} N_{\mathrm{c}}}{\varepsilon^{2} N_{\mathrm{c}}+t^{2} \delta^{2}}
$$

where $t$ is the value of the normalized deviate at a certain confidence probability (for example, when the confidence probability $P=0,95$ then $t=1,96[13])$;

$\delta$ - standard deviation;

$N_{\mathrm{c}}$ - city population;

$\varepsilon-$ maximum permissible error (the recommended reference value is 0,05 [13]).

For the repeated sampling, the sample size can be defined as

$$
n \geq \frac{t^{2} \sigma^{2}}{\varepsilon^{2}} .
$$

Since there were no data about the waiting time, its mathematical expectation and standard deviation, it was necessary to conduct a pilot survey to estimate mentioned parameters. The survey was conducted during one day at the stop served by public transport route with a timetable-based service. Collected data were processed in "Statistica" software $[14,15]$, and the normal distribution [16] was fitted to the waiting time, Fig. 2.

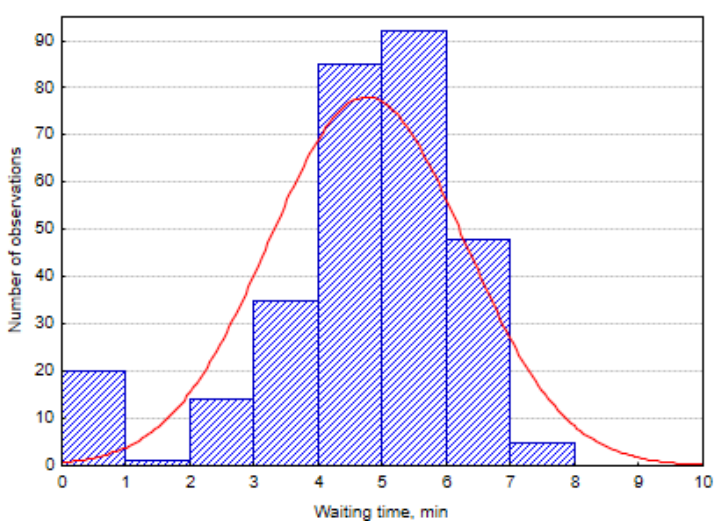

Fig. 2. Waiting time distribution when the type of service on the route is timetable-based

The main statistics calculated using the "Statistica" are given in Table 1.

Table 1 - The main statistical characteristics of the waiting time distribution when the type of service is timetable-based

\begin{tabular}{|c|c|c|c|c|}
\hline $\begin{array}{c}\text { Number of } \\
\text { observations }\end{array}$ & $\begin{array}{c}\text { Expec- } \\
\text { tation, } \\
\text { min }\end{array}$ & $\begin{array}{c}\text { Mini- } \\
\text { mum, } \\
\text { min }\end{array}$ & $\begin{array}{c}\text { Maxi- } \\
\text { mum, } \\
\text { min }\end{array}$ & $\begin{array}{c}\text { Standard } \\
\text { deviation, } \\
\text { min }\end{array}$ \\
\hline 300 & 4.76 & 0.50 & 8.00 & 1.53 \\
\hline
\end{tabular}

Based on the received statistics, the size of the repeated sample according to formula (17) will be

$$
n \geq \frac{1,96^{2} \cdot 1,53^{2}}{0,05^{2}}=3614 \text { passengers }
$$

Thus, to analyze the waiting time variable for the case when the type of service is timetablebased, it is necessary to obtain a sample of more than 3614 values. These data were collected during the corresponding survey and then processed using "Statistica". Statistical processing allowed confirming that the random waiting time values can be well-described by the normal distribution 
[16], Fig. 3.

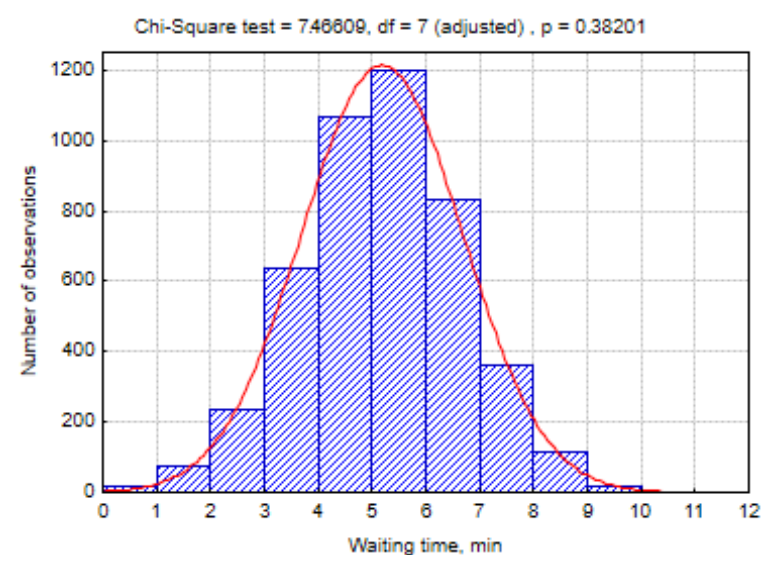

Fig. 3. The result of the analysis performed in module "Distribution Fitting"

The main distribution statistics calculated using "Statistica" are in Table 2.

Table 2 - The characteristics of the waiting time distribution when the type of service is timetable-based

\begin{tabular}{|c|c|c|c|c|c|}
\hline $\begin{array}{c}\text { Number } \\
\text { of obser- } \\
\text { vations }\end{array}$ & $\begin{array}{c}\text { Expec- } \\
\text { tation, } \\
\text { min }\end{array}$ & $\begin{array}{c}\text { Mini- } \\
\text { mum, } \\
\text { min }\end{array}$ & $\begin{array}{c}\text { Maxi- } \\
\text { mum, } \\
\text { min }\end{array}$ & $\begin{array}{c}\text { Standard } \\
\text { deviation, } \\
\text { min }\end{array}$ & $\begin{array}{c}\text { Stan- } \\
\text { dard } \\
\text { error }\end{array}$ \\
\hline 4562 & 5.19 & 0.10 & 10.20 & 1.50 & 0.02 \\
\hline
\end{tabular}

In general, the figure shows that the distribution of the analyzed variable corresponds to the normal one. This conclusion based on visual conformity has a more strict confirmation by the results of the $\chi$-square test (see the top of the graph). The $\chi$-square tests the null hypothesis that the observed distribution does not differ from the theoretical normal distribution. Since the confidence level $P$ appeared to be more than 0.05 (namely, $P=0,38201$ ) and the tabulated value $\chi_{0.05 ; 8}^{2}=15.51$ ( 8 is the number of degrees of freedom that equals to the difference between the number of distribution bins and the number of estimated statistical characteristics [17]) appeared to be greater than calculated, the hypothesis was considered confirmed.

To support this conclusion, the other tests were applied [18]. The most preferable among them is the Shapiro-Wilk $W$-test (Fig. 4) since it has the greatest power compared to others (i.e. it often reveals differences between distributions when these differences really exist) $[17,18]$.

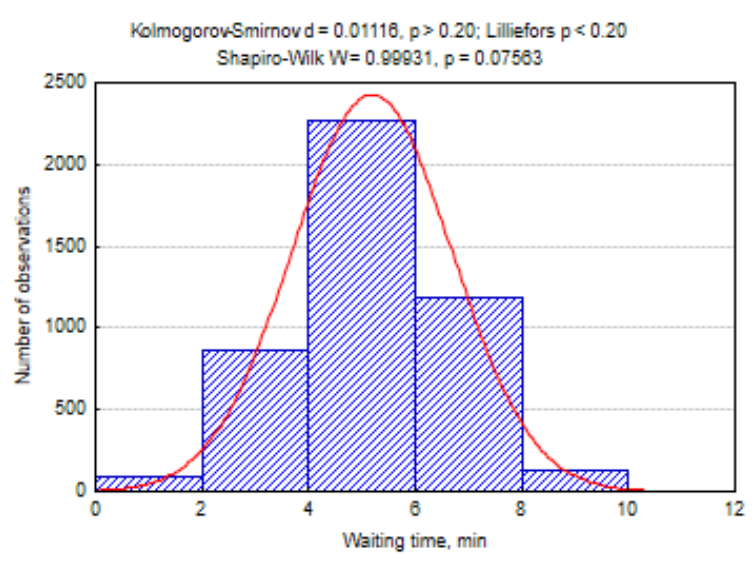

Fig. 4. The result of checking the waiting times' normality performed using module "Descriptive Statistics"

As in the previous case, the confidence level $P$ appeared to be more than 0.05 , and it approves that the analyzed distribution does not differ significantly from the normal one. Thus, the results of experimental studies allowed defining that when the type of service is timetable-based, the average waiting time is $5.2 \mathrm{~min}$. The use of this value in formula (16) will result in

$$
I=\sqrt{0.0867^{2}+0.0186}+0.0867=0.25 \text { hour } .
$$

\section{Conclusion}

The result of the research allowed determining that the headway on the public transport route at which it is advisable to organize the provision of timetable-based service equals 0.25 hour or 15 minutes.

\section{References}

1. Скирковский С.В. Повышение эффективности городских перевозок пассажиров автобусами. Вест. Белорусского гос. ун-та транспорта: Наука и транспорт. 2006. № 1-2. С. 97-101.

2. Bell M.G.H., Bonsall P.W., Leake G.R., May A.D., Nash C.A., O'Flaherty C.A. Transport Planning and Traffic Engineering (C.A. O'Flaherty Ed.). Oxford: Butterworth-Heinemann. 1997. $544 \mathrm{p}$.

3. Horbachov P., Chyzhyk V. Ocena czasu oczekiwania na przystankach dla losowych zgłoszeń pasażerów. Trip Modelling and Travel Forecasting: Res. and Tech. Papers of Polish Ass. for Transp. Eng. in Cracow (Proc. of 4th sc.-tech. conf. "Modelling 2014", 12-13 June 2014, Cracow). Cracow: Politechnika Krakowska. 2014. P. 75-86.

4. Psarros I., Kepaptsoglou K., Karlaftis M.G. An Empirical Investigation of Passenger Waiting time Perceptions Using Hazard-Based Duration Mod- 
els. Journal of Public Transportation. 2011. Vol. 14, no. 3. P. 109-122.

5. Esfeh M.A., Wirasinghe S.C., Saidi S., Kattan L. Waiting time and headway modelling for urban transit systems - a critical review and proposed approach. Transport Reviews. 2021. Vol. 41:2. P. 141-163.

6. De Gruyter C., Currie G., Truong L.T., Naznin F. A meta-analysis and synthesis of public transport customer amenity valuation research. Transport Reviews. 2019. Vol. 39(2), P. 261-283.

7. Transportation Research Board. Transit capacity and quality of service manual (TCRP report 165). Washington: The National Academies Press. 2013. $685 \mathrm{p}$.

8. Ortuzar J.D., Willumsen L.G. Modelling Transport: 4th ed. Chichester: John Wiley \& Sons Ltd. 2011. $586 \mathrm{p}$.

9. Скирковский С.В. Совершенствование системы управления городским пассажирским транспортом. Наука - образованию, производству, экономике: Материалы междунар. науч.-техн. конф. Т. 1 (Минск, Технопринт, 2003). С. 261265.

10. Daganzo C.F., Ouyang Y. Public Transportation Systems: Basic Principles of System Design, Operations Planning and Real-time Control. New Jersey: World Scientific Publishing. 2019. 350 p.

11. Скирковский С.В. Совершенствование структуры парка подвижного состава пассажирского автопредприятия. Уральский научный вестник. 2007. № 2(3). С. 26-32.

12. Основные итоги переписи населения. Национальный состав, Численность населения URL: http://census.belstat.gov.by/Intro.aspx.

13. Montgomery D.C., Runger G.C. Applied Statistics and Probability for Engineers: $6^{\text {th }}$ ed. New York: John Wiley \& Sons, 2014. 792 p.

14. STATISTICA Quick Reference. StatSoft. Tulsa. 2011. 304 p.

15. Скирковский С.В. Исследование закономерностей движения автобусов и времени ожидания поездки. Коммунальное хозяйство городов. 2006. № 69. С. 254-257.

16. Forbes C., Evans M., Hastings N., Peacock B. Statistical distributions: 4th ed. Hoboken: Wiley. 2011. 227 p.

17. Корчагин В.А., Жилин И. В. Научные основы эксперимента на транспорте. Липецк: ЛГТУ. 2003. $176 \mathrm{c}$.

18. Nornadiah R., Yap W.B. Power comparisons of Shapiro-Wilk, Kolmogorov-Smirnov, Lilliefors and Anderson-arling tests. Journal of Statistical Modeling and Analytics. 2011. Vol. 2(1). P. 2133.

\section{References}

1. Skirkouski, S. (2006). Povyshenie effektivnosti gorodskih perevozok passazhirov avtobusami [Improving the efficiency of urban bus passenger transportation]. Bulletin of the Belarusian State
University of Transport: Science and transport. Vol. 1-2. P. 97-101 [in Russian].

2. Bell M.G.H., Bonsall P.W., Leake G.R., May A.D., Nash C.A., O’Flaherty C.A. (1997). Transport Planning and Traffic Engineering (C.A. O'Flaherty Ed.). Oxford. 544 p.

3. Horbachov P., Chyzhyk V. (2014). Ocena czasu oczekiwania na przystankach dla losowych zgłoszeń pasażerów. Trip Modelling and Travel Forecasting: Res. and Tech. Papers of Polish Ass. for Transp. Eng. in Cracow (Proc. of 4th sc.-tech. conf. "Modelling 2014", 12-13 June 2014, Cracow). Cracow: Politechnika Krakowska. P. 75-86.

4. Psarros I., Kepaptsoglou K., Karlaftis M.G. (2011). An Empirical Investigation of Passenger Waiting time Perceptions Using Hazard-Based Duration Models. Journal of Public Transportation. Vol. 14, no. 3. P. 109-122.

5. Esfeh M.A., Wirasinghe S.C., Saidi S., Kattan L. (2021). Waiting time and headway modelling for urban transit systems - a critical review and proposed approach. Transport Reviews. Vol. 41:2. P. 141-163.

6. De Gruyter C., Currie G., Truong L.T., Naznin F. (2019). A meta-analysis and synthesis of public transport customer amenity valuation research. Transport Reviews. Vol. 39(2), P. 261-283.

7. Transportation Research Board (2013). Transit capacity and quality of service manual (TCRP report 165). Washington. $685 \mathrm{p}$.

8. Ortuzar J.D., Willumsen L.G. (2011). Modelling Transport: 4th ed. Chichester. 586 p.

9. Skirkouski S. (2003). Sovershenstvovanie sistemy upravlenija gorodskim passazhirskim transportom [Improving the management system of urban passenger transport]. Science - education, production, economy: Materials of Int. sc.-tech. conf. Vol. 1 (Minsk, Tekhnoprint). P. 261-265 [in Russian].

10. Daganzo C.F., Ouyang Y. (2019). Public Transportation Systems: Basic Principles of System Design, Operations Planning and Real-time Control. New Jersey. 350 p.

11. Skirkouski S. (2007). Sovershenstvovanie struktury parka podvizhnogo sostava passazhirskogo avtopredprijatija [Improving the fleet structure of passenger transport enterprisw]. Ural Scientific Bulletin. Vol. 2(3). P. 26-32 [in Russian].

12. Osnovnye itogi perepisi naselenija. Nacionalnyj sostav, Chislennost naselenija [The Main Results of the Census. National Composition. Population]. Retrieved from: http://census.belstat.gov.by/Intro.aspx [in Belarussian] (last accessed: 01.12.2015).

13. Montgomery D.C., Runger G.C. (2014) Applied Statistics and Probability for Engineers: $6^{\text {th }}$ ed. New York. 2014. 792 p.

14. STATISTICA Quick Reference (2011). Tulsa. $304 \mathrm{p}$.

15. Skirkouski, S. (2006). Issledovanie zakonomernostej dvizhenija avtobusov $i$ vremeni ozhidanija poezdki [Research of the regularities in bus fre- 
quency and time of waiting to travel]. Municipal economy of cities. Vol. 69. P. 254-257.

16. Forbes C., Evans M., Hastings N., Peacock B. (2011). Statistical distributions: 4th ed. Hoboken. $227 \mathrm{p}$.

17. Korchagin V.A., Zhilin I.V. (2003). Nauchnye osnovy jeksperimenta na transporte [Scientific Basics for Experimenting on Transport]. Lipetsk. $176 \mathrm{p}$.

18. Ramachandran K.M., Tsokos C.P. (2015). Mathematical Statistics with Applications. London. 803 p.

Siarhei Skirkouski ${ }^{1}$, Ph.D., Associate Professor of the Department of Road Transport and Traffic Management, tel. +375-232-953996,

Sergej-Ski3359@yandex.ru

Uladzimir Sedziukevich ${ }^{2}$, Ph.D., Associate Professor of the Department of Transport Systems and Technologies, tel. (8-017) 331-29-68,

sedziukevich@tut.by

Olha Svichynska ${ }^{3}$, Ph.D., Associate Professor of Transport Systems and Logistics Department, tel. +380509931997, svichinskayaolga@gmail.com

${ }^{1}$ Belorussian State University of Transport, 34 Kirova street, Gomel, 246022, Republic of Belarus

${ }^{2}$ Belarusian National Technical University, 65 Nezavisimosti avenue, Minsk, 220013, Republic of Belarus

${ }^{3}$ Kharkiv National Automobile and Highway University, 25 Yaroslava Mudroho street, Kharkiv, 61002, Ukraine.

Обгрунтування вибору форми надання послуг громадського транспорту на маршруті

Анотація. Проблема. На сьогодні існує два основних типи надання послуг пасажирам на марирутах громадського транспорту - за інтервалом руху та за розкладом руху. Вони відрізняються частотою обслуговування зупинок та інформацією, доступною пасажирам. Необхідна частота обслуговування громадським транспортом суттево впливає на витрати транспортного підприсмства та час пересування пасажирів, що має вплив на вартісну оцінку витраченого пасажиром часу. Одним із способів зменшення витрат для обох сторін перевізного процесу $\epsilon$ обтрунтований вибір форми обслуговування пасажирів або ї̈ зміна протягом дня залежно від величини пасажиропотоку. Мета. У статті для обтрунтування вибору між формами надання послуг пасажирам вразо- вуються вартість експлуатації транспортних засобів громадського транспорту та втрати часу пасажирів на пересування. Методологія. Розроблений спосіб вибору форми надання послуг дозволяє підвищити ефективність міського громадського транспорту за рахунок скорочення часу очікування пасажирів шляхом переключення з обслуговування за інтервалом в години пік на обслуговування за розкладом в періоди спаду пасажиропотоку. Результати. Розроблена залежність, що дозволяє приймати рімення про форму надання послуг на маршруті громадського транспорту. Це дозволяє обтрунтовано запроваджувати форму обслуговування, щуо забезпечить баланс між витратами транспортного перевізника та пасажирів. Орихінальність. Розроблений підхід для прийняття рішення щзодо форми обслуговування дозволяє скоротити час очікування пасажирів шляхом переключення 3 обслуговування за інтервалом у години пік на обслуговування за розкладом у періоди зменшення величини пасажиропотоку протягом доби. Практичне значення. Результати дослідження, основані на даних обстеження, дозволили оцінити чисельне значення інтервалу руху транспортних засобів громадського транспорту, коли дочільно перейти на обслуговування пасажирів за розкладом руху.

Ключові слова: пасажирські перевезення, громадський транспорт, форма обслуговування, інтервал руху, час очікування.

\section{Скірковський Сергій Володимирович ${ }^{1}$,} доц. каф. «Управління автомобільними перевезеннями і дорожнім рухом»,

тел. +375 2329539 96, Sergej-Ski3359@yandex.ru Седюкевич Володимир Миколайович ${ }^{2}$, к.т.н., доц. каф. «Транспортні системи і технології», тел. (8-017) 331-29-68, sedziukevich@tut.by

Свічинська Ольга Володимирівна ${ }^{3}$, к.т.н., доц. каф. транспортних систем і логістики,

тел. +38 050-993-19-97, svichinskayaolga@ gmail.com

${ }^{1}$ Білоруський державний університет транспорту, 246022, Республіка Білорусь, м. Гомель, вул. Кірова, 34

${ }^{2}$ Білоруський національний технічний університет, 220013, Республіка Білорусь, м. Мінськ, пр. Незалежності, 65

${ }^{3}$ Харківський національний автомобільно-дорожній університет, 61002, Україна, м. Харків, вул. Ярослава Мудрого, 25. 